\title{
Hubungan Kecemasan, Pengetahuan, dan Interaksi dengan Stigma Perawat terhadap Pasien HIV/AIDS di RSUD Dr. H. Abdul Moeloek Provinsi Lampung
}

\section{Related of Knowledge, Anxiety, and Interaction toSstigma among Nurses Concern to HIV/AIDS Patients in Hospital Dr. H. Abdul Moeloek Lampung Province in 2020.}

\author{
Nurul Aryastuti ${ }^{1}$, Renita Sari ${ }^{2}$, Dhiny Easter Yanti ${ }^{1}$ \\ ${ }^{1}$ Fakultas Kesehatan Masyarakat, Universitas Malahayati, Bandar Lampung, \\ Indonesia \\ ${ }^{2}$ Rumah Sakit Umum Daerah Dr. H. Abdul Moeloek Provinsi Lampung, Indonesia \\ Korespondensi: nurularyastuti@gmail.com
}

Penyerahan: 25-08-2020, Perbaikan: 09-09-2020, Diterima: 16-01-2021

\begin{abstract}
Stigma among nurses to the people with HIV / AIDS (PLWHA) may reduce the quality of healthcare services for HIV / AIDS patients. Data at Hospital Dr. H. Abdul Moeloek of Lampung Province known that HIV/AIDS cases were increase in 2016, 2017 and 2018 with 189 people, 195 people, 343 peoplerespectively. Efforts to improve healthcare services for the quality of life of PLWHA through prevention and control of HIV/ AIDS according to the Three Zero target in 2030 that is no more stigma and discrimination in PLWHA. The aim research was to identify the relation of knowledge, anxiety, and interaction to stigma among nurses concern to HIV / AIDS patients in Dr. H. Abdul Moeloek Lampung Province in 2020. This research use analytic survey design with cross-sectional approach. The population in this study were all nurses in the Anyelir, Nuri, PBH, Mahanmunyai, and Sudhanirmala A Hospital Dr. H. Abdul Moeloek of Lampung Province with 109 nurses. A sample of 97 nurses was taken by simple random technique. The statistical test used the chi square test. The results are stigma among nurses was mostly negative as many as 52 (53.6\%); Mostly of nurses' anxiety was within normal limits as 64 (66\%); most of the nurses had low knowledge of $85(87.6 \%)$; most of nurses had good interactions of 57 (58.8\%). There is a relationship between nurses 'anxiety with stigma among nurses concern to HIV / AIDS patients ( $p$ value $=0.039, O R=2.78$ ); There is a relationship between interactions with stigma among nurse concern to HIV / AIDS patients ( $p$ value = $0.12, O R=3.21$ ). Hospital management is expected to facilitate nurses through seminars or training on HIV / AIDS on a regular basis in order to improve nursing services or care in the management of HIV/AIDS patients so as to eliminate the negative stigma against patients with HIV / AIDS.
\end{abstract}

Keywords: Stigma; Knowledge; Anxiety; Interaction; HIV/AIDS

\begin{abstract}
ABSTRAK
Stigma perawat pada Orang Dengan HIV/AIDS (ODHA) dapat menurunkan kualitas layanan kesehatan pasien HIV/AIDS. Data di RSUD Dr. H. Abdul Moeloek Provinsi Lampung diketahui kasus HIV/AIDS dirawat tahun 2016 sampai 2018 meningkat (189 orang, 195 orang, 343 orang). Salah satu cara meningkatkan kualitas hidup ODHA dengan menghilangkan stigma dan diskriminasi. Tujuan penelitian untuk mengetahui hubungan kecemasan, pengetahuan, dan interaksi dengan stigma perawat terhadap pasien HIV/AIDS di Rumah Sakit Umum Daerah Dr. H. Abdul Moeloek Provinsi Lampung Tahun 2020. Jenis penelitian menggunakan rancangan survey analitik dengan pendekatan crosssectional. Populasi penelitian adalah perawat di ruang Anyelir, Nuri, PBH, Mahammunyai,
\end{abstract}


dan Sudhanirmala A RSUD Dr. H. Abdul Moeloek Provinsi Lampung sejumlah 109 perawat. Sampel sebanyak 97 perawat diambil dengan teknik simple random. Uji statistik yang digunakan adalah uji chi square. Hasil Penelitian didapatkan stigma perawat sebagian besar negatif sebanyak $52(53,6 \%)$; sebagian besar kecemasan perawat dalam batas normal sebanyak $64(66 \%)$; sebagian besar perawat memiliki pengetahuan rendah sebanyak $85(87,6 \%)$; sebagian besar perawat memiliki interaksi baik sebanyak 57 $(58,8 \%)$. Ada hubungan antara kecemasan perawat dengan stigma perawat terhadap pasien HIV/AIDS ( $p$ value $=0,039, \mathrm{OR}=2,78$ ); Ada hubungan antara interaksi dengan stigma perawat terhadap pasien HIV/AIDS ( $p$ value $=0,12, O R=3,21$ ). Pihak manajemen rumah sakit diharapkan dapat memfasilitasi perawat melalui seminar atau pelatihan tentang HIV/AIDS secara berkala agar dapat meningkatkan layanan atau asuhan keperawatan dalam penatalaksanaan pasien HIV/AIDS sehingga dapat menghilangkan stigma negatif terhadap pasien dengan HIV/AIDS.

Kata Kunci: Stigma; Pengetahuan; Kecemasan; Interaksi; HIV/AIDS

\section{PENDAHULUAN}

Human Immunodeficiency

Virus (HIV) adalah virus yang menginfeksi sel darah putih sehingga kekebalan tubuh manusia turun (Kemenkes RI, 2014). HIV/AIDS menjadi penyebab kematian karena replika virus yang sangat cepat menginfeksi sel pejamu (sel T-helper) secara berkelanjutan untuk menggandakan dirinya dan menyebar ke sel selanjutnya, hal ini yang mengakibatkan kerusakan sistem kekebalan tubuh yang akan berakhir dengan kematian (Brunner, Smeltzer, \& Suddarth, 2010).

Kasus HIV dan AIDS beberapa tahun terakhir mencapai jumlah yang fantastis, yaitu sejumlah 25,5 juta orang hidup dengan HIV diperkirakan $40 \%$ tidak mengetahui bahwa mereka memiliki virus. Permasalahan HIV dan AIDS telah menjadi tantangan kesehatan hampir di seluruh dunia, termasuk di Indonesia. Data Word Health Organization (WHO) didapat orang dengan HIV di Asia tenggara sejumlah 3,8juta; Indonesia sejumlah 46.000 (WHO,2018).

Kasus HIV/AIDS di Provinsi Lampung bukan termasuk 10 besar namun masalah HIV dan AIDS beberapa tahun terakhir menunjukkan peningkatan jumlah kasus, yaitu tahun 2015 sejumlah 345 kasus, 2016 sejumlah 381 kasus, tahun 2017 sejumlah 580 kasus, dan tahun 2018 sejumlah 512 kasus; Januari-Juni 2019 sejumlah 228 kasus (Kemenkes, 2019). Data di Rumah Sakit Umum Daerah Dr. H. Abdul Moeloek Provinsi Lampung diketahui kasus HIV/AIDS dirawat tahun 2016 kasus sebanyak 189 orang, tahun 2017 sebanyak 195 orang, tahun 2018 sebanyak 343 orang (Data RSUDAM, 2018).

$$
\text { Kemenkes RI }
$$

menyebutkan bahwa permasalahan kasus HIV yang dilaporkan belum maksimal, terlihat bahwa data Januari hingga Juni 2019 sebesar 50\% data kasus HIV yang dilaporkan hanya $33 \%$ orang dengan HIV yang rutin melakukan pengobatan. Menurut Shaluhiyah, Musthofa, dan Widjanarko (2015) hambatan dalam mengoptimalkan pencegahan dan penanggulangan HIV/AIDS di Indonesia adalah adanya stigma dan diskriminasi terhadap orang dengan HIV/AIDS.

Friedland et al (2018) menemukan sebagian besar responden melaporkan pernah mengalami bentuk stigma terkait HIV, seperti pengucilan dari keluarga, sosial, kegiatan keagamaan, 
pelecehan verbal atau fisik, atau pemerasan. Senegal, negara dengan laporan terendah tentang stigma terkait HIV juga ditemukan sebesar $33 \%$ populasi mengalami bentuk stigma sedangkan di Kamerun ditemukan sebesar $76 \%$ dan Uganda $53 \%$. Di Indonesia, stigma telah menjadi penghambat utama untuk mencegah dan mengobati HIV/AIDS (Aggarwal et al., 2018).

Diperkirakan sekitar 50\% lakilaki dan perempuan mengalami stigma dan perlakuan diskriminasi terkait dengan status HIV-nya di 35\% negara di dunia (United Nations Programme on HIV/AIDS (UNAIDS \& Organization, 2014). Di Lampung, Nurfalah, Yona, \& Waluyo (2019) memeriksa 120 pasien dengan HIV dan ditemukan bahwa perempuan dengan tingkat stigma yang rendah terhadap HIV menunjukkan kepatuhan terhadap pengobatan ARV 2,27 kali lebih besar dari pada perempuan dengan stigma tingkat tinggi terhadap HIV.

Stigma dan diskriminasi pada orang dengan HIV/AIDS (ODHA) digambarkan bentuk perilaku cenderung dikucilkan oleh keluarga, teman-temannya dan lingkungan yang lebih luas. Pada sisi lain mereka juga mengalami diskriminasi dalam pelayanan kesehatan, pendidikan dan hak-hak lainnya. Indeks stigma terhadap ODHA mengindikasikan bahwa 1 dari 8 ODHA tidak mendapat pelayanan kesehatan karena stigma dan diskriminasi (Brown, 2018; Ardani \& Handayani, 2017).

Peningkatan kualitas hidup orang dengan HIV dan AIDS yang telah dilakukan pemerintah yaitu melalui upaya peningkatan peran petugas kesehatan untuk mencapai tujuan target three zero yang ketiga yaitu tidak ada lagi stigma dan diskriminasi pada ODHA. Stigma tidak hanya dilakukan pada masyarakat awam yang memiliki pengetahuan kurang tentang HIV/AIDS tetapi juga dilakukan oleh petugas kesehatan yang memiliki pengetahuan lebih baik dibanding masyarakat awam. Hal ini sejalan dengan penelitian Belize bahwa petugas kesehatan mempunyai stigma dan melakukan diskriminasi pada orang dengan HIV/AIDS (Andrewin \& Chien, 2008). Petugas kesehatan dipandang sebagai faktor penguat untuk melaksanakan perubahan kearah perilaku yang lebih sehat pada setiap individu. Penelitian Hoffart et al. (2012) menunjukkan bahwa terdapat penurunan sikap profesional untuk merawat pasien dengan infeksi HIV diantara tenaga kesehatan. Stigma yang terjadi pada lingkungan pelayanan kesehatan merupakan suatu permasalahan yang serius pada sistem layanan kesehatan. Apabila terdapat pasien terinfeksi HIV dan merasa terstigma oleh petugas kesehatan, maka hal tersebut dapat mempengaruhi kualitas perawatan, kualitas hidup pasien, dan keterlibatan dalam proses perawatan. Munculnya stigma perawat sebagian besar karena kekhawatiran terhadap banyaknya kasus penularan HIV/AIDS pada perawat yang ditemukan berasal dari rangkaian kecelakaan yang terjadi akibat paparan cairan tubuh pasien ketika melakukan perawatan. Sebagai contohnya yaitu kecelakaan akibat luka tusukan jarum suntik yang mengandung darah terinfeksi HIV atau luka dari benda tajam lainnya yang terkontaminasi dengan darah pasien positif HIV (De, 2008). Menurut Nyblade, Stangl, Weiss, and Ashburn (2009) terdapat tiga faktor utama yang menyebabkan munculnya stigma pada fasilitas pelayanan kesehatan. Faktor tersebut meliputi ketakutan tertular virus HIV, kurangnya terpapar informasi terkait penularan HIV, serta sikap dan perilaku terkait stigmatisasi bahwa 
Tabel 1. Distribusi frekuensi stigma, kecemasan, pengetahuan, dan interaksi perawat terhadap pasien HIV/AIDS

\begin{tabular}{llcc}
\hline & Variabel & \multicolumn{2}{c}{ Jumlah } \\
& & f & \% \\
\hline \multirow{2}{*}{ Stigma } & Negatif & 52 & 53,6 \\
\multirow{3}{*}{ Kecemasan } & Positif & 45 & 46,4 \\
\multirow{3}{*}{ Pengetahuan } & cemas & 33 & 34 \\
& Tidak cemas (Normal) & 64 & 66 \\
Interaksi & Rendah & 85 & 87,6 \\
& Tinggi & 12 & 12,4 \\
& Kurang & 40 & 41,2 \\
& Baik & 57 & 58,8 \\
& Total & 97 & 100 \\
\hline
\end{tabular}

Tabel 2. Hubungan kecemasan, pengetahuan, interaksi dengan stigma perawat terhadap pasien HIV/AIDS

\begin{tabular}{|c|c|c|c|c|c|c|c|c|c|}
\hline \multicolumn{3}{|c|}{ Variabel } & \multicolumn{4}{|c|}{ Stigma } & \multirow[b]{2}{*}{ Total } & \multirow[b]{2}{*}{$\begin{array}{c}p \\
\text { Value }\end{array}$} & \multirow{2}{*}{$\begin{array}{c}\text { OR } \\
(95 \% \mathrm{CI})\end{array}$} \\
\hline & & & \multicolumn{2}{|c|}{$\begin{array}{l}\text { Negatif } \\
\text { n } \%\end{array}$} & \multicolumn{2}{|c|}{ Positif } & & & \\
\hline Kecemasan & $\begin{array}{l}\text { Cemas } \\
\text { Tidak } \\
\text { (normal) }\end{array}$ & cemas & $\begin{array}{l}23 \\
29\end{array}$ & $\begin{array}{l}69,7 \\
45,3\end{array}$ & $\begin{array}{l}10 \\
35\end{array}$ & $\begin{array}{l}30,3 \\
54,7\end{array}$ & $\begin{array}{l}33 \\
64\end{array}$ & 0,039 & $\begin{array}{c}2,78 \\
(1,14- \\
6,76)\end{array}$ \\
\hline Pengetahuan & $\begin{array}{l}\text { Rendah } \\
\text { Tinggi }\end{array}$ & & $\begin{array}{c}52 \\
0\end{array}$ & $\begin{array}{c}61,2 \\
0\end{array}$ & $\begin{array}{l}33 \\
12\end{array}$ & $\begin{array}{c}38,8 \\
100\end{array}$ & $\begin{array}{l}85 \\
12\end{array}$ & - & - \\
\hline Interaksi & $\begin{array}{l}\text { Kurang } \\
\text { Baik }\end{array}$ & & $\begin{array}{l}28 \\
24\end{array}$ & $\begin{array}{c}70 \\
42,1\end{array}$ & $\begin{array}{l}12 \\
33\end{array}$ & $\begin{array}{c}30 \\
57,9\end{array}$ & $\begin{array}{l}40 \\
57\end{array}$ & 0,012 & $\begin{array}{c}3,21 \\
(1,36- \\
7,56)\end{array}$ \\
\hline
\end{tabular}

Tabel 2 menunjukkan bahwa sebagian besar perawat yang memiliki kecemasan dan stigma negatif sebesar 69,7\%; sebagian besar perawat dengan tingkat kecemasan normal memiliki stigma positif sebesar 54,7\%; hasil analisis chi square didapatkan nilai $\mathrm{p}$-value $=$ 0,039 berarti $\mathrm{p}<\mathrm{a}=0,05$ ( $\mathrm{HO}$ ditolak), maka dapat disimpulkan bahwa ada hubungan antara kecemasan dengan stigma perawat terhadap pasien HIV/AIDS. Dari nilai OR dapat disimpulkan bahwa perawat yang memiliki kecemasan memiliki peluang stigma negatif sebesar 2,78 kali lebih besar dibandingkan dengan perawat yang tidak memiliki kecemasan (normal). Sebagian besar perawat dengan pengetahuan rendah memiliki stigma negatif sebesar $61,2 \%$; sebagian besar perawat dengan pengetahuan tinggi memiliki stigma positif sebesar 100\%. Interaksi perawat diketahui sebagian besar kurang memiliki stigma negatif sebesar 70\%; sebagian besar perawat dengan interaksi baik memiliki stigma positif sebesar 57,9\%; hasil analisis chi square didapatkan nilai $p$-value $=0,012$ berarti $p<a=0,05$ ( $\mathrm{H} 0$ ditolak), maka dapat disimpulkan bahwa ada hubungan antara interaksi dengan stigma perawat terhadap pasien HIV/AIDS. Nilai OR=3,21 yang berarti perawat yang interaksi kurang mempunyai peluang 3,21 kali untuk memiliki stigma negatif dibandingkan dengan interaksi baik.

\section{PEMBAHASAN}

a. Hubungan kecemasan dengan stigma perawat

Kecemasan secara statistik memiliki hubungan dengan stigma perawat hal ini sejalan dengan penelitian Nyblade et al. (2009) yang menemukan ketakutan dan kesalahpahaman pada petugas 
kesehatan tentang penularan HIV juga harus diatasi. Ketakutan tertular HIV melalui kontak sehari-hari membuat petugas kesehatan mengambil tindakan yang tidak perlu, dan sering kali menstigmatisasi sebagai bentuk ungkapan kewaspadaan mereka terinfeksi HIV/AIDS saat memberi pelayanan kesehatan.

Penelitian sebelumnya yang sejalan dengan hasil penelitian dapat dijelaskan dari penelitian Erkki dan Hedlund (2013) yang menyatakan bahwa perawat yang memiliki pengetahuan tinggi akan memiliki rasa ketakutan penularan HIV yang rendah dan sikap positif yang lebih baik dibandingkan perawat yang berpengetahuan rendah. Hasil distribusi frekuensi hubungan kecemasan dengan stigma perawat diperoleh bahwa sebagian besar perawat dengan kecemasan memiliki kecenderungan stigma negatif.

Ketakutan terinfeksi HIV/AIDS bahkan kecemasan perawat pada pasien masalah yang umum dialami. Hal ini sesuai dengan penelitian De Villiers (2008) yang menemukan bahwa para perawat menjelaskan sulit bagi mereka untuk merawat pasien HIV/AIDS karena mereka mengetahui bahwa mereka berisiko tertular HIV. Besarnya risiko yang perawat hadapi merupakan tuntutan pekerjaan dan tanggungjawabnya yang harus dilakukan demi menyeimbangkan daya tahan diri (resiliensi) terhadap kinerja pekerjaan. Penelitian Mariani (2017) menemukan bahwa perawat yang memiliki kepercayaan atau keyakinan yang tinggi terhadap kemampuan dirinya akan semakin kuat menghadapi masalah dalam pekerjaannya.

Berdasarkan uraian diatas peneliti berpendapat bahwa kecemasan ada hubungan dengan stigma perawat dapat dikaitkan dengan hasil beberapa penelitian sebelumnya yang menemukan faktor penyebab kecemasan perawat juga dilatarbelakangi oleh pendidikan, menurut Gao, et al. (2012) pendidikan yang lebih tinggi diperoleh $11,6 \%$ memiliki kecemasan yang lebih tinggi dibandingkan dengan yang pendidikan rendah. Hasil penelitian didapatkan perawat yang memiliki pendidikan perawat S1 $30,9 \%$, sedangkan pendidikan D3 $66 \%$. Hasil ini sesuai dengan penelitian sebelumnya bahwa perawat yang tidak memiliki kecemasan namun ditemukan memiliki stigma positif sebagian besar dilatarbekangi pendidikan D3 yang termasuk dalam kelompok pendidikan tinggi.

\section{b. Hubungan pengetahuan dengan} stigma perawat

Penelitian sesuai dengan penelitian Febrianti (2017) yang berjudul Faktor-faktor yang berhubungan dengan stigma terhadap ODHA di kalangan remaja SMA seKecamatan Senapelan Kota Pekanbaru tahun 2016. Hasil penelitian diperoleh ada hubungan yang signifikan antara Pengetahuan (POR: 2,180; CI 95\% ; 1,119-4,250) yang berarti pengetahuan kurang memiliki risiko 2 kali untuk memiliki stigma berat pada ODHA dibandingkan dengan pengetahuan baik.

Menurut Nyblade, Stangl, Weiss, and Ashburn (2009) terdapat tiga faktor utama yang menyebabkan munculnya stigma di fasilitas pelayanan kesehatan. Faktor tersebut meliputi ketakutan tertular virus HIV, kurangnya terpapar informasi terkait penularan HIV, serta sikap dan perilaku terkait stigmatisasi bahwa HIV merupakan dampak dari perilaku amoral.

Informasi yang diperoleh baik dari pendidikan formal maupun non 
formal dapat memberikan pengaruh jangka pendek pada pengetahuan seseorang, sehingga menghasilkan perubahan atau peningkatan pengetahuan. Feldman-Stewart et al (2013) menemukan pemberian informasi yang lebih rinci dapat memiliki dampak besar pada pengetahuan, sehingga dapat mempengaruhi kemampuan untuk memahami danmengintegrasikan informasi dalam pengambilan keputusan. Penelitian Yuliza (2019) menemukan bahwa ada hubungan yang bermakna antara pengetahuan dengan perilaku pencegahan HIV/AIDS ( $p$ value $=0,002$ ).

Pengetahuan baik menjadi dasar perawat untuk melakukan tindakan pencegahan penularan HIV/AIDS. Tidak sedikit anggapan perilaku pencegahan penularan infeksi HIV/AIDS sudah cukup didapatkan untuk melindungi perawat dari infeksi, sehingga upaya meningkatkan informasi tidak dilakukan. Pandangan atau persepsi negatif akibat stigma dapat dihindari dengan upaya peningkatan pengetahuan melalui perbanyaknya mncari informasi sehingga perawat dapat memberikan tindakan yang tepat pada pasien HIV/AIDS.

\section{c. Hubungan interaksi dengan stigma perawat}

Interaksi umumnya dikaitkan dengan bentuk kepedulian atau empaty perawat terhadap pasien. Kontak antara perawat dan pasien dengan frekuensi yang lebih sering dibanding dengan tenaga medis lain menurut Lee, et al. (2019) dapat meningkatkan freuensi diskriminasi, terutama ketika adanya kontak perawatan tindakan invasif. Tindakan invasif memiliki risiko yang besar menularkan HIV memalui darah akibat kecelakaan jarum suntik. Ketakutan ini lah yang dapat meningkatkan frekuensi diskriminasi terhadap orang yang hidup dengan HIV.

Hasil penelitian sesuai dengan penelitian Febrianti (2017) yang berjudul Faktor-faktor yang berhubungan dengan stigma terhadap ODHA di kalangan remaja SMA seKecamatan Senapelan Kota Pekanbaru tahun 2016 menemukan hasil ada hubungan yang signifikan antara Interaksi dengan stigma ODHA (POR : 3,841; CI 95\%: 1,275-11,569) yang berarti pengalaman berinteraksi dengan ODHA memberi peluang 4 kali lebih besar untuk memiliki perilaku stigma yang ringan dibandingkan dengan yang tidak pernah berinteraksi.

Interaksi perawat yang bekerja di fasilitas kesehatan terutama ketika merawat pasien HIV/AIDS sangat beresiko terpapar infeksi karena adanya interaksi dalam memberikan asuhan keperawatan kepada pasien seperti kontak langsung dengan cairan tubuh atau darah pasien. Hal itu mengharuskan perawat selalu menerapkan prosedur tindakan pencegahan universal mutlak pada seluruh kegiatan saat interaksi dengan pasien HIV/AIDS. Semakin tinggi nilai mean praktik pencegahan umum terhadappenularan HIV/AIDS menunjukkan semakin banyak responden yang melaporkan selalu melaksanakan praktik tersebut sebagai stigma terhadap pasien HIVAIDS (Ibrahim et al., 2014).

Interaksi selama merawat pasien HIV yang memiliki risiko besar tertular menyebabkan pengurangan kontak dengan pasien HIV. Hasil Penelitian menyatakan bahwa selama 3 dekade terakhir, HIV telah menjadi bidang perawatan kesehatan yang khusus. Sebagai akibatnya, pasien tidak memiliki interaksi yang cukup dengan petugas kesehatan. Dalam penelitiannya juga didapatkan gambaran pasien yang merasakan interaksi yang tidak memadai, 
bahkan ungkapan pengakuan dan sensitivitas terhadap stigma(Davtyan, Olshansky, Brown, \& Lakon, 2017). Penelitian De Villiers (2008) menemukan bahwa para perawat menjelaskan bahwa sulit bagi mereka untuk merawat pasien HIV/AIDS karena mereka mengetahui bahwa mereka berisiko tertular HIV.

Interaksi perawat dapat dilihat dengan cara mengukur sejauh apa perawat berperan, baik secara kompetensi dan asuhan teknis, bahkan hubungan interpersonal dianggap sebagai caring behavior (perilaku peduli). Hasil penelitian menemukan bahwa perawat dengan interaksi kurang mempunyai peluang 3,21 kali untuk memiliki stigma negatif dibandingkan dengan yang memiliki interaksi baik. Beberapa penelitian menemukan bahwa interaksi perawat memiliki risiko besar terinfeksi HIV/AIDS melalui kontak cairan dan darah selama perawatan sehingga menuntut perawat melakukan tindakan dengan hati-hati sesuai prosedur dalam praktik.

\section{KESIMPULAN}

Ada hubungan antara
kecemasan dan interaksi perawat
dengan stigma perawat terhadap
pasien HIV/AIDS di Rumah Sakit Dr.
H. Abdul Moeloek Provinsi Lampung
Tahun 2020. Hubungan antara
pengetahuan perawat dengan stigma
tidak dapat dianalisis karena tidak
memenuhi syarat uji chi Square.

\section{SARAN}

Pihak manajemen rumah sakit diharapkan dapat memfasilitasi perawat melalui seminar atau pelatihan tentang HIV/AIDS secara berkala agar dapat meningkatkan layanan atau asuhan keperawatan dalam penatalaksanaan pasien HIV/AIDS sehingga dapat menghilangkan stigma negatif terhadap pasien dengan HIV/AIDS.

\section{DAFTAR PUSTAKA}

Aggarwal, S., Yu, L., Hasjim, B., Lee, D. H., Kim, E., Lee, J. B., ... Diamond, C. (2018). Stigma and negative self-perceptions of young people living with human immunode $\mathrm{fi}$ ciency virus in Bandung, Indonesia: a case series. International Health, 10(June), 401-403. https://doi.org/10.1093/inthealth /ihy031

Andrewin, A., \& Chien, L. (2008). Stigmatization of Patients with HIV / AIDS among Doctors and Nurses in Belize. AIDS Patient Care and STDs, 22(11), 897-906. https://doi.org/10.1089/apc.2007 .0219

Ardani, I., \& Handayani, S. (2017). Stigma terhadap Orang dengan HIV / AIDS (ODHA) sebagai Hambatan Pencarian Pengobatan : Studi Kasus pada Pecandu Narkoba Suntik di Jakarta. Buletin Penelitian Kesehatan, 45(2), 8188.

Ardhiyanti, Y., Lusiana, N., \& Megasari, K. (2015). Bahan ajar AIDS pada asuhan kebidanan. Yogyakarta: DEEPUBLISH. Retrieved from https://books.google.co.id/books? id $=$ ej.

Brown, L. D. (2018). Foundations for Global Health Practice.

Brunner, L. S., Smeltzer, S. C. O., \& Suddarth, D. S. (2010). Textbook of medical-surgical nursing (12th ed.). Philadelphia: Wolters Kluwer Health/Lippincott Williams \& Wilkins.

Davtyan, M., Olshansky, E. F., Brown, B., \& Lakon, C. (2017). A Grounded Theory Study of HIVRelated Stigma in U.S. -Based Health Care Settings. Journal of the Association of Nurses in AIDS 
Care, 28(6), 1-16. https://doi.org/10.1016/j.jana.20 17.07 .007

De, V. (2008). South african professional nurses' experiences of caring for hiv/aids patients. Journal of Nursing and Midwifery, $10(1), 5-21$.

Erkki, L., \& Hedlund, J. (2013). Nurses' experiences and perceptions of caring for patients with HIV/AIDS in Uganda.

Febrianti. (2017). Faktor-faktor yang berhubungan dengan stigma terhadap orang dengan HIV/AIDS (ODHA). Jurnal Endurance. Vol.2 (2), 158-167

Feldman-Stewart, D., O'Brien, M. A., Clayman, M. L., Davison, B. J., Jimbo, M., Labrecque, M., ... \& Shepherd, H. (2013). Providing information about options in patient decision aids. BMC medical informatics and decision making, 13(2), s4.

Friedland, B. A., Sprague, L., Nyblade, L., Baral, S. D., Pulerwitz, J., Gottert, A., \& Jackson, A. (2018). Measuring intersecting stigma among key populations living with HIV: implementing the people living with HIV Stigma Index 2.0. Journal of the International AIDS Society, 21(Suppl Suppl 5).

Gao, Y. Q., Pan, B.C., Sun, W., Wu, H., Wang, J.N., Wang, L. (2012). Anxiety symptoms among Chinese nurse and the associated factor: a cross sectional study. BMC Psychiatry, 12:141

Hoffart, S., Ibrahim, G. M., Lam, R. A., Minty, E. P., Theam, M., \& Schaefer, J. P. (2012). Medical students' attitudes towards treating patients with HIV: a 12year follow-up study. Medical teacher, 34(3), 254-254.

Ibrahim, K., Mardiah, W., \& Priambodo, A. P. (2014). Pengetahuan, sikap, dan praktik kewaspadaan universal perawat terhadap penularan hiv/aids. Jurnal Ners, 9(1), 11-18.

Kemenkes, R. I. Laporan perkembangan HIV AIDS \& penyakit infeksi menular seksual (PIMS) triwulan II tahun 2019 (2019).

Lee, H., Kim, D., Na, Y., Kwon, M., Yoon, H., Lee, W., \& Woo, S. (2019). Factors Associated with HIV/AIDS-Related Stigma and Discrimination by Medical Professionals in Korea: A Survey of Infectious Disease Specialists in Korea. Nigerian Journal of Clinical Practice, 22(5), 675-681.

Mariani, B. U. (2017). Faktor-Faktor Personal Sebagai Prediktor Terhadap Resiliensi Perawat Di Rumah Sakit Penyakit Infeksi Prof. Dr. Sulianti Saroso. The Indonesian Journal of Infectious Diseases, 1(01), 14-21.

Nyblade, L., Stangl, A., Weiss, E., \& Ashburn, K. (2009). Combating HIV stigma in health care settings: what works? Journal of the International AIDS Society, 17(1), 15.

https://doi.org/10.1186/17582652-12-15

Paryati, T., Raksanagara, A. S., \& Afriandi, I. (2012). Faktor-faktor yang Mempengaruhi Stigma dan Diskriminasi kepada ODHA ( Orang dengan HIV / AIDS ) oleh petugas kesehatan : kajian literatur Factors Influencing Stigmatization and Discrimination of PLHA ( People living with HIV / AIDS ) among health workers . Program Pascasarjana Universitas Padjadjaran, (38), 1-11.

Reyes-Estrada, M., Varas-Díaz, N., Parker, R., Padilla, M., \& Rodríguez-Madera, S. (2018). Religion and HIV-related stigma among nurses who work with people living with HIV/AIDS in Puerto Rico. Journal of the 
International Association of Providers of AIDS Care (JIAPAC), $17,2325958218773365$.

RSUD Abdul Moeloek (2018). Data rekam medis RSUDAM: HIV/AIDS

Shaluhiyah, Z., Musthofa, S. B., \& Widjanarko, B. (2015). Stigma masyarakat terhadap orang dengan HIV/AIDS. Kesmas: National Public Health Journal, 9(4), 333-339.

UNAIDS, \& Organization, W. H. (2014). Global AIDS response progress reporting 2014: construction of core indicators for monitoring the 2011 United
Nations political declaration on HIV and AIDS. Geneva: UNAIDS.

WHO (2018). Global Health Observatory (GHO) data: HIV/AIDS

Wilandika, A. (2019). Health care provider stigma on People Living with HIV/AIDS (PLWHA) in Bandung. Jurnal Keperawatan, 10(1), 7-15.

Yuliza, W. T., Hardisman, \& Nursal, D. G. A. (2019). Factors related to the behavior of HIV/AIDS Prevention in female sex workers in Padang Tahun 2018. Sains. 